\title{
PENGARUH METODE LATIHAN DAN KECERDASAN EMOSIONAL TERHADAP HASIL BELAJAR MATA DIKLAT ILMU STATIKA DAN TEGANGAN SISWA KELAS $X$ SMK NEGERI BINAAN PROVINSI SUMATERA UTARA
}

\author{
Chita Sri Lestika ${ }^{1}$, Kristian $^{2}$ \\ ${ }^{1}$ Alumni Program Studi Pendidikan Teknik Bangunan, Fakultas Teknik UNIMED \\ ${ }^{2}$ Dosen Pengajar Jurusan Pendidikan Teknik Bangunan, Fakultas Teknik UNIMED \\ (kristianritongan@gmail.com)
}

\begin{abstract}
ABSTRAK
Penelitian ini bertujuan untuk mengetahui pengaruh metode latihan terhadap hasil belajar mata diklat Ilmu Statika dan Tegangan dengan melihat karakteristik kecerdasan emosional siswa dalam pembelajaran. Subjek penelitian ini adalah siswa kelas X Teknik Gambar Bangunan dengan jumlah 48 orang yang terdiri dari kelas X Teknik Gambar Bangunan 1 untuk perlakuan dengan metode latihan sebanyak 24 orang dan kelas X Teknik Gambar Bangunan 2 untuk perlakuan dengan metode konvensional sebanyak 24 orang.Sebelum penelitian ini dilakukan instrument penelitian terlebih dahulu di uji cobakan, dilanjutkan dengan uji validitas dan uji reabilitas. Uji validitas butir tes digunakan rumus korelasi Product Moment Perarson. Uji reliabislitas tes digunakan rumus KR-20. Instrument tes hasil belajar mata diklat Ilmu Statika dan Tegangan yang valid diperoleh 24 butir dari 30 butirtes yang di uji cobakan, dan koefisien reliabilitasnya sebesar 0,81. Teknik pengumpulan data hasil belajar dengan menggunakan rancangan penelitian menggunakan desain Anava 2 × 2 . Variabel penelitian memenuhi persyaratan normalitas diuji dengan uji Liliefors dan homogenitas diuji dengan uji F dan uji Barlett. Hasil pengujian menunjukkan bahwa : (1) terdapat pengaruh yang positif antara metode latihan terhadap hasil belajar mata diklat Ilmu Statika dan Tegangan ditunjukkan $\mathrm{F}_{\text {hitung }}=8,975>\mathrm{F}_{\text {tabel }}=4.06$ pada taraf signifikansi $a=5 \%$. (2) terdapat pengaruh yang positif antara kecerdasan emosional terhadap hasil belajar mata diklat Ilmu Statika dan Tegangan ditunjukkan $\mathrm{F}_{\text {hitung }}=8,975>\mathrm{F}_{\text {tabel }}=4.06$ (3) Terdapat interaksi antara metode latihan dan kecerdasan emosional terhadap hasil belajar mata diklat Ilmu Statika dan Tegangan, hal ini ditunjukkan diperolehnya $\mathrm{F}_{\text {hitung }}=17,731>\mathrm{F}_{\text {tabel }}=4.06$ pada taraf signifikansi $5 \%$.
\end{abstract}

Kata kunci: Metode latihan, Kecerdasan Emosional, Ilmu Statika, Tegangan

\begin{abstract}
This research aim to know the influence Method of Practice and Emotional Intelligence about Result of Learning the subject of training and education program Science of Statics and Tension about characteristic student in studying. The Subject from this Research is student class $X$ in program Technique Drawing of Building amounts 48 students who consisted of the class $X$ program Technique Drawing of Building the first for treated with the method of practice as much 24 students and the second for treated with the conventional method as much 24 people. Before this research conducted with the instrument research beforehand in the test of try out, continued with the validity test and the reliability test. The validity test of item used a formula of correlation of Product Moment Perarson. The reliability test used a formula KR-20. The Instrument test about result learning the subject of training and education program Science of statics and valid Tension obtained 24 item from 30 question which is in the test of try out, and coefficient reliability of equal to 0,81 . Technique to collect file about result of learning by using research device use the design Anava $2 \times 2$. Research variable fulfill the conditions normally tested with the test of Liliefors and homogeneity tested with the test F and the test of Barlett. Test result shown that:
\end{abstract}




\section{Chika Sri Lestika - Kristian}

(1) there is a positive effect of exercise on learning outcomes mothods about Result of Learning the subject of training and education program Science of Statics shown by $\mathrm{F}_{\text {count }}=8,975>\mathrm{F}_{\text {list }}=4.06$ at level significant $5 \%$ (2) there is a positive effect of emotional intelligence on learning outcomes about Result of Learning the subject of training and education program Science of Statics shown by $F_{\text {count }}=8,975>F_{\text {list }}=$ 4.06 (3) There are interaction between exercise and emotional intelligence and study with the result learning subject of training and education program Science of Statics and Tension, this is shown obtaining of $F_{\text {count }}=17,731>F_{\text {list }}=4.06$ at level significant $5 \%$.

Keywords: Pratice Method, Emotional Intelligence, Science of Statics, Tension

\section{Pendahuluan}

SMK mempunyai tiga jenis mata diklat yang digolongkan menjadi mata diklat normatif, adaptif dan produktif. Dari ketiga golongan mata diklat ini, mata diklat Ilmu Statika dan Tegangan termasuk golongan mata diklat produktif yang merupakan mata dilkat yang meliputi program keahlian yang berhubungan langsung dengan keterampilan siswa. Siswa dituntut untuk mempunyai pengetahuan, keterampilan dan kemampuan yang merupakan bekal bagi para siswa. Penelitian yang dilakukan oleh peneliti adalah khusus untuk Program Keahlian Teknik Gambar Bangunan, untuk mata diklat yang diambil adalah Ilmu Statika dan Tegangan kelas X. Mata diklat Ilmu Statika dan Tegangan adalah proses pengajaran teknik dan kejuruan yang penting karena Ilmu Statika dan Tegangan dapat mengantarkan siswa kepada dasar memahami program produktif lainnya.

Berdasarkan observasi awal yang penulis lakukan di SMK Negeri Binaan Provinsi Sumatera Utara, nilai hasil belajar Ilmu Statika dan Tegangan pada siswa kelas $X$, mata diklat Menerapkan Ilmu Statika dan Tegangan yang diperoleh siswa pada tahun ajaran 2013/2014 Program Keahlian Teknik Gambar Bangunan dengan jumlah siswa 24 orang, persentase nilai siswa yang memperoleh nilai kurang dari 70-79 sebanyak 58,33\% (14 orang), dan yang memperoleh nilai $80-89$ sebanyak 41,67\% (10 orang). Melihat daftar hasil belajar tersebut, masih ada persentase siswa yang perlu ditingkatkan. Kriteria Ketuntasan Minimum (KKM) untuk mata diklat produktif adalah 75 sesuai standar kelulusan mata diklat Ilmu Statika dan Tegangan pada SMK Negeri Binaan Provinsi Sumatera Utara, hal tersebut menjadi bukti bahwa hasil belajar mata pelajaran Ilmu Statika dan Tegangan yang diperoleh oleh siswa masih ada yang dibawah nilai 75 .

Banyak faktor yang mempengaruhi hasil belajar siswa pada diklat Ilmu Statika dan Tegangan di SMK Negeri Binaan Provinsi Sumatera Utara dalam proses belajar mengajar yang terjadi di dalam kelas. Faktor-faktor penyebab rendahnya hasil belajar siswa tersebut antara lain: banyak siswa yang berpendapat bahwa Ilmu Statika dan Tegangan adalah pelajaran yang sulit, sehingga sebahagian besar siswa kurang menyenangi pelajaran tersebut. Hal ini yang berdampak pada hasil belajar mereka. Disamping itu pelajaran hanya berpusat pada guru, di mana dalam pengajaran guru menjelaskan materi pelajaran dan siswa hanya mendengarkan dan mencatat apa yang disampaikan oleh guru. Proses pembelajaran ini terlihat sekedar sebagai proses tranfer pengetahuan berupa materi pelajaran kepada siswa sehingga sebahagian besar siswa mudah merasa bosan saat proses pembelajaran berlangsung. Padahal pembelajaran mendapat tempat yang lebih luas, harus menjadi wahana untuk penumbuhkembangan potensi-potensi siswa melalui peran aktif mereka menuju perubahan yang lebih baik. Dalam keadaan ini sangat diperlukan upaya-upaya nyata guru dalam mengembangkan dimensi-dimensi emosional siswa agar mereka semangkin mampu menghadapi berbagai persoalan, bersemangat, ulet, tekun, bertanggung jawab, mampu menjalin komunikasi secara sehat dengan individu atau kelompok lain. Karena hal inilah siswa merasa sulit untuk berpikir dan mencerna materi yang diberikan oleh guru. Akibatnya siswa tidak berpartisipasi atau pasif, dan juga menimbulkan rasa kebosanan dalam proses belajar.

Padahal kualitas proses belajar mengajar di kelas ditentukan oleh beberapa faktor, salah satu 


\section{Pengaruh Metode Latihan dan Kecerdasan Emosional Terhadap Hasil Belajar Mata Diklat Ilmu Statika dan Tegangan Siawa Kelas X SMK Negeri Binaan Provinsi Sumatera Utara}

diantaranya ialah metode mengajar. Karena metode mengajar ialah cara yang dipergunakan guru dalam mengadakan hubungan dengan siswa pada saat berlangsungnya pengajaran. Sudjana (1998) menyatakan bahwa "Peran metode mengajar adalah sebagai alat untuk menciptakan proses belajar mengajar".

Ada beberapa hal yang perlu dipertimbangkan dalam menentukan metode mengajar, antara lain tujuan pengajaran, bahan pelajaran, jenis kegiatan atau aktivitas belajar siswa, fasilitas belajar yang tersedia dan siswa itu sendiri. Dari uraian di atas, ada beberapa metode yang dapat dipergunakan dalam mengajar, namun dalam penelitian ini digunakan metode latihan, karena metode latihan menambah ketepatan dan kecepatan pelaksanaan, yang dilakukan dengan menumbuhkan pembentukan kebiasaan. Penyajian pelajaran dengan metode latihan dilakukan berulang-ulang untuk mendapatkan hasil yang maksimal.

Metode latihan merupakan suatu cara mengajar dengan memberikan latihan-latihan terhadap apa yang telah dipelajari siswa sehingga memperoleh suatu keterampilan tertentu. Dalam penerapan metode latihan, guru harus memberikan arahan kepada siswa dalam menyelesaikan latihan yang akan dikerjakan, berikan motivasi kepada siswa agar siswa merasa bersemangat dalam mengerjakan latihan, dan hal yang terpenting bagi siswa yaitu tugas yang mereka kerjakan dinilai, agar mereka mengetahui hasil dari pekerjaan yang telah diselesaikan. Terkadang siswa malas menyelesaikan latihan karena guru memberi latihan, namun tidak menindak lanjuti latihan yang diberikan.Selain faktor di atas, masih ada faktor yang mempengaruhi hasil belajar siswa. Faktor tersebut berasal dalam diri siswa (internal) yaitu kecerdasan emosional. Kecerdasan emosional atau Emotional Qoutient (EQ) merupakan ungkapan yang mencakup kemampuan mengelola emosi, mengendalikan emosi, turut merasakan, memotivasi diri serta memahami perasaan orang lain. Goleman (2000) mengatakan bahwa pencapaian suatu prestasi yang maksimal tidak hanya ditentukan oleh kecerdasan intelektual atau lebih dikenal dengan Intelegensi Question (IQ) saja. Tetapi pencapaian prestasi yang maksimal juga ditentukan oleh kecerdasan emosional yang selama ini dikenal dengan istilah karakter pribadi.

Pendidikan yang hanya menitikberatkan pada kemampuan intelektualnya saja, hanya akan melahirkan orang-orang yang pintar namun kurang dapat mengendalikan emosinya. Di sekolah banyak anak yang mengalami depresi, mudah cemas, gelisah dan mudah putus asa, tidak dapat berkonsentrasi, sering melamun dan tidak mempunyai motivasi belajar sehingga mereka mendapat nilai yang kurang memuaskan di sekolah. Hal ini terjadi karena proses belajar mengajar yang kurang memperhatikan aspek psikologis. Sisi buruk dari pendidikan yang kurang seimbang seperti ini harus dihindari, terutama di era kehidupan yang semangkin modern yang lebih banyak faktor yang menyebabkan gangguan emosional.

Keberadaan kecerdasan emosional tentu saja sangat berpengaruh terhadap prestasi belajar. Karena dengan adanya kecerdasan emosional yang baik, maka akan diperoleh motivasi, semangat, dorongan, kemauan belajar, dan kesadaran serta kearifan diri yang lebih baik untuk meningkatkan kemampuan diri. Dengan pengembangan kecerdasan emosional yang terjadi pada sebuah forum pembelajaran akan dapat membangkitkan perhatian siswa pada materi pelajaran yang sedang dipelajari. Suasana kelas akan semangkin hidup, karena masingmasing individu akan melakukan kegiatan pembelajaran tanpa adanya perasaan tertekan.

Darwis (2008) menjelaskan langkah-langkah dalam metode latihan adalah:

a. sebelum latihan dilaksanakan, siswa harus diberi penjelasan mengenai arti atau manfaat dan tujuan dari latihan tersebut.

b. Setelah siswa memahami konsep, siswa diberikan soal-soal latihan untuk di kerjakan. Latihan hendaknya dilakukan secara bertahap, dimulai dari yang sederhana kemudian ke taraf yang lebih kompleks atau sulit.

c. Selama latihan berlangsung, perhatikanlah bagian-bagian mana yang sebagian besar anak-anak dirasakan sulit. Ketika siswa mengerjakan latihan-latihan soal, guru hendaknya memantau secara langsung hasil pekerjaan siswa, guru bisa mengecek hasil pekerjaan tiap siswa, sehingga guru bisa 
mengetahui di bagian-bagian mana saja siswa mengalami kesulitan.

d. Setelah guru mengetahui di mana letak kesulitan siswa, guru harus memberikan penjelasan kembali tentang materi yang dianggap sulit oleh siswa tersebut serta menambah kuantitas latihan soal-soal sehingga siswa bisa lebih memahami materi tersebut,

e. Evaluasi ini sebaiknya dilakukan setiap akhir pertemuan, dengan cara siswa harus mengumpulkan hasil latihan-latihan soal yang telah dikerjakan siswa sehingga guru dapat mengecek pada bagian mana saja siswa mengalami kesulitan dan guru bisa membahasnya kembali pada pertemuan minggu berikutnya. Selain itu dengan memberikan tugas untuk siswa juga dapat dikatakan evaluasi.

Robert K. Cooper (Agustin A.G, 2001), berpendapat bahwa kecerdasan emosional adalah kemampuan merasakan, memahami dan secara efektif menerapkan daya dan kepekaan emosi sebagai sumber energi, informasi, koneksi dan pengaruh yang manusiawi.

Dalam diklat Ilmu Statika dan Tegangan, kecerdasan emosional sangat dibutuhkan, dalam hal ini sangat membutuhkan kesabaran, kecermatan dan mampu memotivasi dirinya dalam mengikuti pelajaran yang memerlukan konsentrasi yang tinggi. Kecerdasan emosional yang merupakan hasil latihan dan pengalaman yang didapat siswa melalui peristiwa yang berbeda. Semakin banyak siswa mendapatkan latihan dan pengalaman maka semakin banyak yang dapat di pelajari siswa untuk dapat memunculkan ungkapan emosional yang tepat.

Dengan penggunaan metode latihan dan kecerdasan emosional yang baik maka siswa dapat meraih hasil belajar Ilmu Statika dan Tegangan yang baik pula, sehingga akan tercapai nilai standar kompetensi kelulusan yang di tetapkan. Dari uraian diatas diduga terdapat pengaruh positif antara metode latihan dan kecerdasan emosional terhadap hasil belajar siswa Ilmu Statika dan Tegangan.

\section{Metodologi Penelitian}

Penelitian ini dilakukan di SMK Negeri Binaan Provinsi Sumatera Utara Jl. Karya Dalam No. 26 dan waktu penelitian dilakukan pada bulan Februari Tahun 2015. Penetapan pertemuan disesuaikan dengan jadwal yang telah di tetapkan disekolah.

Dalam penelitian ini yang menjadi populasi adalah seluruh siswa kelas X SMK Negeri Binaan Provinsi Sumatera Program Keahlian Teknik Gambar Banguan. Pada setiap kelas terdiri dari 24 orang siswa. Teknik pengambilan sampel pada penelitian ini siswa kelas X SMK Negeri Binaan Sumatera Utara dilakukan secara cluster random sampling dengan pengundian kelas yaitu menuliskan nama ketiga kelas pada kertas yang digulungkan dan dipilih. Hasil pengundian diperoleh Kelas X TGB-1 dengan jumlah siswa sebanyak 24 orang sebagai kelas eksperimen menggunakan metode latihan dan X TGB-2 dengan jumlah yang sama yaitu sebanyak 24 orang sebagai kelas kontrol menggunakan pembelajaran konvensional. Dengan demikian jumlah keseluruhan sampel dalam penelitian ini adalah sebanyak 48 siswa.

Penelitian ini menggunakan metode eksperimen dengan rancangan quasi eksperimen desain faktorial $2 \times 2$ (Arikunto, 2000) untuk melihat ada tidaknya pengaruh metode latihan dan kecerdasan emosional terhadap hasil belajar mata diklat Ilmu Statika dan Tegangan.

Tabel 1 Rancangan Faktorial 2 × 2

\begin{tabular}{|c|c|c|}
\hline \multirow{2}{*}{$\begin{array}{l}\text { Kecerdasan } \\
\text { Emosional(B) }\end{array}$} & \multicolumn{2}{|c|}{$\begin{array}{c}\text { Metode Pembelajaran } \\
(\mathrm{A})\end{array}$} \\
\cline { 2 - 3 } & $\begin{array}{c}\text { Metode } \\
\text { Latihan } \\
\left(\mathrm{A}_{1}\right)\end{array}$ & $\begin{array}{c}\text { Pembelajaran } \\
\text { Konvensional } \\
\left(\mathrm{A}_{2}\right)\end{array}$ \\
\hline Tinggi $\left(\mathrm{B}_{1}\right)$ & $\mathrm{A}_{1} \mathrm{~B}_{1}$ & $\mathrm{~A}_{2} \mathrm{~B}_{1}$ \\
\hline Rendah $\left(\mathrm{B}_{2}\right)$ & $\mathrm{A}_{1} \mathrm{~B}_{2}$ & $\mathrm{~A}_{2} \mathrm{~B}_{2}$ \\
\hline
\end{tabular}

Keterangan :

A : Metode Pembelajaran

B : Kecerdasan Emosional

$\mathrm{A}_{1}$ : Metode Latihan

$\mathrm{A}_{2}$ : Pembelajaran Konvensional

$\mathrm{B}_{1}$ : Kecerdasan Emosional tinggi

$\mathrm{B}_{2}$ : Kecerdasan Emosional rendah

$A_{1} B_{1}$ : Hasil belajar dari kelompok siswa yang menggunakan metode latihan pada siswa dengan kecerdasan emosional tinggi.

$A_{1} B_{2}$ : Hasil belajar dari kelompok siswa yang menggunakan metode latihan pada 


\section{Pengaruh Metode Latihan dan Kecerdasan Emosional Terhadap Hasil Belajar Mata Diklat Ilmu Statika dan Tegangan Siawa Kelas X SMK Negeri Binaan Provinsi Sumatera Utara}

siswa dengan kecerdasan emosional rendah.

$\mathrm{A}_{2} \mathrm{~B}_{1}$ : Hasil belajar dari kelompok siswa yang menggunakan pembelajaran konvensional pada siswa dengan kecerdasan emosional tinggi.

$A_{2} B_{2}$ : Hasil belajar dari kelompok siswa yang menggunakan pembelajaran konvensional pada siswa dengan kecerdasan emosional rendah.

Pengumpulan data dilakukan dengan menggunakan tes objektif untuk data hasil belajar Ilmu Statika dan Tegangan dan angket/kuesioner untuk data kecerdasan emosional. Langkah penyusunan instrumen penelitian berdasarkan konsep, kemudian dirumuskan kedalam bentuk defenisi operasional yang kemudian dijabarkan dalam bentuk kisi-kisi. Dari kisi-kisi tersebut kemudian dibuat menjadi butir-butir soal berupa pertanyaan dan pernyataan. Respon yang diharapkan dalam bentuk pilihan ganda dan dengan memberi tanda silang dari salah satu 4 pilihan.

Tes psikologi untuk mengetahui peluang sukses seseorang adalah emosional intelegensi, yaitu untuk mengetahui tingkat kecerdasan emosi seseorang. Instrumen yang disusun oleh peneliti mengacu pada hakekat-hakekat ubahan dan aspeknya serta beberapa instrument berdasarkan kecerdasan emosional yang telah diuraikan terlebih dahulu, dirumuskan kedalam bentuk defenisi operasional yang kemudian dijabarkan dalam bentuk kisi-kisi dibuat menjadi butir-butir soal/item. Angket disusun berupa pertanyaan favorabel dan pertanyaan tidak favorabel. Untuk mengumpulkan data kecerdasan emosional dilakukan penjaringan dengan mengunakan angket sebanyak 50 soal dengan 4 pilihan jawaban : SS (Sangat Setuju), S (Setuju), TS (Tidak Setuju), STS (Sangat Tidak Setuju). Untuk menghindari kesamaan jawaban sebagian dari angket di buat dalam arah favorabel dan sebagian lagi di buat dalam arah tidak favorabel (Azwar, 2000). Pemberian skor angket dalam arah favorabel yaitu : SS diberi nilai 4, S diberi nilai 3, TS diberi nilai 2, STS diberi nilai 1. Pemberian nilai dalam arah tidak favorabel yaitu SS diberi nilai 1, S diberi nilai 2, TS diberi nilai 3, STS diberi nilai 4 .
Angket diberikan pada akhir pelakuan, untuk menentukan siswa yang memiliki kecerdasan emosional tinggi dan siswa yang memiliki kecerdasan emosional rendah dilihat dari perilaku siswa saat mengikuti proses pembelajaran. Setelah hasil data angket telah diperoleh maka untuk menentukan tingkat kecendrungan (tinggi rendah) dari kecerdasan emosional digunakan rumus ideal (Mi) sebagai berikut:

$$
M i=\frac{\text { Skor tertinggi }+ \text { Skor terendah }}{2}
$$

Jika sekor kecerdasan emosional lebih besar dari skor ideal (>Mi) maka kecerdasan emosional siswa dinyatakan cendrung tinggi, sebaliknya jika skor kecerdasan emosional siswa lebih rendah dari skor ideal (<Mi) maka kecerdasan emosional siswa dinyatakan cendrung rendah.

Data tes hasil belajar Memahami Bahan Bangunan diperoleh melalui tes pemberian tes objektif pada siswa setelah perlakuan diberikan, dengan 4 (empat) pilihan jawaban, yaitu 1 (satu) pilihan yang benar dan 3 (tiga) pilihan pengecoh. Penyusunan atau pembuatan soal untuk tes hasil belajar Ilmu Statika dan Tegangan diambil dari pelajaran kelas X Program Keahlian Teknik Gambar Bangunan.

\subsection{Hasil Belajar Siswa yang Diajarkan dengan Metode Latihan}

Berdasarkan tes hasil belajar yang diberikan setelah proses pemberian perlakuan, skor tertinggi pada siswa yang diajar dengan menggunakan metode latihan memiliki skor ratarata $(\mathrm{Ma})=18,667$; standar deviasi $(\mathrm{Sd})=2,352$; varians $\left(\mathrm{Sd}^{2}\right)=5,536$; skor tertinggi $=23$; skor terendah $=13$.

\subsection{Hasil Belajar Siswa yang Diajarkan dengan Pembelajaran Konvensional}

Berdasarkan tes hasil belajar yang diberikan setelah proses pemberian perlakuan, skor tertinggi pada siswa yang diajar dengan menggunakan pembelajaran konvensional memiliki skor rata-rata $(\mathrm{Ma})=$ 18,04; standar deviasi $(\mathrm{Sd})=2,475$; varians $\left(\mathrm{Sd}^{2}\right)=6,128$; skor tertinggi $=23$; skor terendah $=13$. 
2.3 Kecerdasan Emosional yang Diajarkan dengan Metode Latihan

Dari data yang diperoleh dapat diketahui bahwa siswa yang memiliki kecerdasan emosional yang diajarkan dengan metode latihan memiliki skor rata-rata $(\mathrm{Ma})=143,708$; standar deviasi $(\mathrm{Sd})=14,414$; varians $\left(\mathrm{Sd}^{2}\right)=207,780$; skor tertinggi $=169$; skor terendah $=110$.

Tabel 2 Kecerdasan Emosional yang Diajarkan dengan Metode Latihan

\begin{tabular}{|c|c|c|c|c|}
\hline \multicolumn{5}{|c|}{ DATA KELAS X TGB 1} \\
\hline No. & $\begin{array}{c}\text { No } \\
\text { Subjek }\end{array}$ & Post Test & $\begin{array}{c}\text { Kec. } \\
\text { Emosional }\end{array}$ & Ket \\
\hline 1 & 1 & 20 & 160 & B1 \\
\hline 2 & 2 & 17 & 155 & B1 \\
\hline 3 & 3 & 19 & 141 & B1 \\
\hline 4 & 4 & 20 & 150 & B1 \\
\hline 5 & 5 & 13 & 138 & B1 \\
\hline 6 & 6 & 18 & 131 & B1 \\
\hline 7 & 7 & 23 & 156 & B1 \\
\hline 8 & 8 & 17 & 142 & B1 \\
\hline 9 & 9 & 18 & 161 & B1 \\
\hline 10 & 10 & 20 & 148 & B1 \\
\hline 11 & 11 & 17 & 144 & B1 \\
\hline 12 & 12 & 16 & 126 & B1 \\
\hline 13 & 13 & 21 & 153 & B1 \\
\hline 14 & 14 & 21 & 123 & B2 \\
\hline 15 & 15 & 19 & 110 & B2 \\
\hline 16 & 16 & 15 & 169 & B1 \\
\hline 17 & 17 & 20 & 148 & B1 \\
\hline 18 & 18 & 20 & 138 & B1 \\
\hline 19 & 19 & 19 & 145 & B1 \\
\hline 20 & 20 & 16 & 163 & B1 \\
\hline 21 & 21 & 18 & 123 & B2 \\
\hline 22 & 22 & 19 & 143 & B1 \\
\hline 23 & 23 & 19 & 131 & B1 \\
\hline 24 & 24 & 23 & 151 & B1 \\
\hline \multicolumn{2}{|r|}{$\mathrm{Ma}$} & 18,667 & 143,7083 & \\
\hline \multicolumn{2}{|r|}{$\sum X$} & 448 & 3449 & \\
\hline \multicolumn{2}{|c|}{$\sum X^{2}$} & 8490 & 500429 & \\
\hline \multicolumn{2}{|r|}{ Sd } & 2,35292 & 14,41460361 & \\
\hline \multicolumn{2}{|r|}{$\mathrm{Sd}^{2}$} & 5,536232 & 207,7807971 & \\
\hline \multicolumn{2}{|r|}{$\mathrm{N}$} & 24 & & \\
\hline
\end{tabular}

\subsection{Kecerdasan Emosional yang Diajar dengan Metode Konvensional}

Dari data yang diperoleh dapat diketahui bahwa siswa yang memiliki kecerdasan emosional yang diajar dengan metode konvensional memiliki skor rata-rata $(\mathrm{Ma})$ $=141,666$; standar deviasi $(\mathrm{Sd})=16,732$; varians
$\left(\mathrm{Sd}^{2}\right)=279,959$; skor tertinggi $=168$; skor terendah $=107$.

Tabel 3 Kecerdasan Emosional yang Diajarkan dengan Metode Konvensional

\begin{tabular}{|c|c|c|c|c|}
\hline \multicolumn{5}{|c|}{ DATA KELAS X TGB 2} \\
\hline No. & $\begin{array}{c}\text { No. } \\
\text { Subjek }\end{array}$ & Post Test & $\begin{array}{c}\text { Kec. } \\
\text { Emosional }\end{array}$ & Ket. \\
\hline 1 & 1 & 18 & 140 & B1 \\
\hline 2 & 2 & 22 & 168 & B1 \\
\hline 3 & 3 & 16 & 118 & B2 \\
\hline 4 & 4 & 21 & 152 & B1 \\
\hline 5 & 5 & 18 & 143 & B1 \\
\hline 6 & 6 & 16 & 152 & B1 \\
\hline 7 & 7 & 19 & 155 & B1 \\
\hline 8 & 8 & 17 & 118 & $\mathrm{~B} 2$ \\
\hline 9 & 9 & 14 & 124 & B2 \\
\hline 10 & 10 & 18 & 160 & B1 \\
\hline 11 & 11 & 16 & 141 & B1 \\
\hline 12 & 12 & 20 & 145 & B1 \\
\hline 13 & 13 & 20 & 154 & B1 \\
\hline 14 & 14 & 15 & 107 & $\mathrm{~B} 2$ \\
\hline 15 & 15 & 13 & 124 & $\mathrm{~B} 2$ \\
\hline 16 & 16 & 18 & 162 & B1 \\
\hline 17 & 17 & 17 & 150 & B1 \\
\hline 18 & 18 & 23 & 151 & B1 \\
\hline 19 & 19 & 18 & 132 & B1 \\
\hline 20 & 20 & 18 & 162 & B1 \\
\hline 21 & 21 & 19 & 123 & B2 \\
\hline 22 & 22 & 21 & 143 & B1 \\
\hline 23 & 23 & 20 & 153 & B1 \\
\hline 24 & 24 & 16 & 123 & $\mathrm{~B} 2$ \\
\hline \multicolumn{2}{|c|}{$\mathrm{Ma}$} & 18,042 & 141,6667 & \\
\hline \multicolumn{2}{|c|}{$\sum X$} & 433 & 3400 & \\
\hline \multicolumn{2}{|c|}{$\sum X^{2}$} & 7953 & 488106 & \\
\hline \multicolumn{2}{|c|}{$\mathrm{Sd}$} & 2,475606 & 16,7323344 & \\
\hline \multicolumn{2}{|c|}{$\mathrm{Sd}^{2}$} & 6,128623 & 279,9710145 & \\
\hline \multicolumn{2}{|c|}{ Mmax } & 23 & 168 & \\
\hline \multicolumn{2}{|c|}{ Mmin } & 13 & 107 & \\
\hline \multicolumn{2}{|r|}{$\mathrm{N}$} & 24 & & \\
\hline
\end{tabular}

2.5 Hasil Belajar Siswa yang Memiliki Kecerdasan Emosional Tinggi dan Diajar dengan Metode Latihan

Berdasarkan tes hasil belajar yang diberikan setelah proses pemberian perlakuan, skor tertinggi pada siswa yang memiliki kecerdasan emosional tinggi dan diajar dengan menggunakan metode latihan memiliki skor ratarata $(\mathrm{Ma})=147,28$; varians $\left(\mathrm{Sd}^{2}\right)=125,82$; standar deviasi $(\mathrm{Sd})=11,217$; skor tertinggi $=169$; skor terendah $=126$. 
Tabel 4 Hasil Belajar Siswa yang Memiliki Kecerdasan Emosional Tinggi dan Diajar dengan Metode Latihan

\begin{tabular}{|c|c|c|c|c|}
\hline \multicolumn{5}{|c|}{ DATA KELAS X TGB 1} \\
\hline No. & $\begin{array}{c}\text { No. } \\
\text { Subjek }\end{array}$ & $\begin{array}{l}\text { Post } \\
\text { Test }\end{array}$ & $\begin{array}{c}\text { Kec. } \\
\text { Emosional }\end{array}$ & Ket \\
\hline 1 & 1 & 20 & 160 & B1 \\
\hline 2 & 2 & 17 & 155 & B1 \\
\hline 3 & 3 & 19 & 141 & B1 \\
\hline 4 & 4 & 20 & 150 & B1 \\
\hline 5 & 5 & 13 & 138 & B1 \\
\hline 6 & 6 & 18 & 131 & B1 \\
\hline 7 & 7 & 22 & 156 & B1 \\
\hline 8 & 8 & 17 & 142 & B1 \\
\hline 9 & 9 & 18 & 161 & B1 \\
\hline 10 & 10 & 20 & 148 & B1 \\
\hline 11 & 11 & 17 & 144 & B1 \\
\hline 12 & 12 & 16 & 126 & B1 \\
\hline 13 & 13 & 21 & 153 & B1 \\
\hline 14 & 16 & 15 & 169 & B1 \\
\hline 15 & 17 & 20 & 148 & B1 \\
\hline 16 & 18 & 20 & 138 & B1 \\
\hline 17 & 19 & 19 & 145 & B1 \\
\hline 18 & 20 & 16 & 163 & B1 \\
\hline 19 & 22 & 19 & 143 & B1 \\
\hline 20 & 23 & 19 & 131 & B1 \\
\hline 21 & 24 & 23 & 151 & B1 \\
\hline \multicolumn{2}{|c|}{$\mathrm{Ma}$} & 18,5238 & 147,28571 & \\
\hline \multicolumn{2}{|c|}{$\sum X$} & 389 & 3093 & \\
\hline \multicolumn{2}{|c|}{$\sum \mathrm{X}^{2}$} & 7319 & 458071 & \\
\hline \multicolumn{2}{|c|}{$\mathrm{Sd}$} & 2,38 & 11,216697 & \\
\hline \multicolumn{2}{|c|}{$\mathrm{Sd}^{2}$} & 5,7 & 125,81429 & \\
\hline \multicolumn{2}{|c|}{$\mathrm{N}$} & 21 & & \\
\hline
\end{tabular}

2.6 Hasil Belajar Siswa yang Memiliki Kecerdasan Emosional Rendah dan Diajar dengan Metode latihan

Berdasarkan tes hasil belajar yang diberikan setelah proses pemberian perlakuan, skor tertinggi pada siswa yang memiliki kecerdasan emosional rendah dan diajar dengan menggunakan metode latihan memiliki skor rata-rata $(\mathrm{Ma})=118,66$; varians $\left(\mathrm{Sd}^{2}\right)=56,25$; Standar deviasi $(\mathrm{Sd})=7,50$; skor tertinggi $=123$; skor terendah $=110$.
Tabel 5 Hasil Belajar Siswa yang Memiliki Kecerdasan Emosional Rendah dan Diajar dengan Metode Latihan

\begin{tabular}{|c|c|c|c|c|}
\hline \multicolumn{5}{|c|}{ DATA KELAS X TGB 1} \\
\hline No. & $\begin{array}{c}\text { No. } \\
\text { Subjek }\end{array}$ & Post Test & $\begin{array}{c}\text { Kec. } \\
\text { Emosional }\end{array}$ & Ket \\
\hline 1 & 14 & 21 & 123 & B2 \\
\hline 2 & 15 & 19 & 110 & B2 \\
\hline 3 & 21 & 18 & 123 & B2 \\
\hline \multicolumn{2}{|r|}{$\mathrm{Ma}$} & 19,6667 & 118,6667 & \\
\hline \multicolumn{2}{|r|}{$\sum X$} & 58 & 356 & \\
\hline \multicolumn{2}{|c|}{$\sum X^{2}$} & 1126 & 42358 & \\
\hline \multicolumn{2}{|r|}{ Sd } & 1,527525 & 7,505553499 & \\
\hline \multicolumn{2}{|r|}{$\mathrm{Sd}^{2}$} & 2,3333 & 56,3333 & \\
\hline \multicolumn{2}{|r|}{$\mathrm{N}$} & 3 & & \\
\hline
\end{tabular}

2.7 Hasil Belajar Siswa yang Memiliki Kecerdasan Emosional Tinggi dan Diajar dengan Pembelajaran Konvensional

Berdasarkan tes hasil belajar yang diberikan setelah proses pemberian perlakuan, skor tertinggi pada siswa yang memiliki kecerdasan emosional tinggi dan diajar dengan menggunakan pembelajaran konvensional memiliki skor rata-rata $(\mathrm{Ma})=150,76$; varians $\left(\mathrm{Sd}^{2}\right)=86,816$; standard deviasi $(\mathrm{Sd})=9,317$ skor tertinggi $=168$; skor terendah $=132$.

Tabel 6 Hasil Belajar Siswa yang Memiliki Kecerdasan Emosional Tinggi dan Diajar dengan Pembelajaran Konvensional

\begin{tabular}{|c|c|c|c|c|}
\hline \multicolumn{5}{|c|}{ DATA KELAS X TGB 2 } \\
\hline No. & $\begin{array}{c}\text { No. } \\
\text { Subjek }\end{array}$ & $\begin{array}{c}\text { Post } \\
\text { Test }\end{array}$ & $\begin{array}{c}\text { Kec. } \\
\text { Emosional }\end{array}$ & Ket \\
\hline 1 & 1 & 18 & 140 & B1 \\
\hline 2 & 2 & 22 & 168 & B1 \\
\hline 3 & 4 & 21 & 152 & B1 \\
\hline 4 & 5 & 18 & 143 & B1 \\
\hline 5 & 6 & 16 & 152 & B1 \\
\hline 6 & 7 & 19 & 155 & B1 \\
\hline 7 & 10 & 18 & 160 & B1 \\
\hline 8 & 11 & 16 & 141 & B1 \\
\hline 9 & 12 & 20 & 145 & B1 \\
\hline 10 & 13 & 20 & 154 & B1 \\
\hline 11 & 16 & 18 & 162 & B1 \\
\hline 12 & 17 & 17 & 150 & B1 \\
\hline 13 & 18 & 23 & 151 & B1 \\
\hline 14 & 19 & 18 & 132 & B1 \\
\hline
\end{tabular}


Chika Sri Lestika - Kristian

\begin{tabular}{|c|c|c|c|c|}
\hline 15 & 20 & 18 & 162 & B1 \\
\hline 16 & 22 & 21 & 143 & B1 \\
\hline 17 & 23 & 20 & 153 & B1 \\
\hline \multicolumn{2}{|c|}{$\mathrm{Ma}$} & 19 & 150,7647059 & \\
\hline \multicolumn{2}{|c|}{$\sum X$} & 323 & 2563 & \\
\hline \multicolumn{2}{|c|}{$\sum X^{2}$} & 6201 & 387799 & \\
\hline \multicolumn{2}{|c|}{$\mathrm{Sd}$} & 2 & 9,317519867 & \\
\hline \multicolumn{2}{|c|}{$\mathrm{Sd}^{2}$} & 4 & 86,81617647 & \\
\hline \multicolumn{2}{|c|}{$\mathrm{N}$} & 17 & & \\
\hline
\end{tabular}

2.8 Hasil Belajar Siswa yang Memiliki Kecerdasan Emosional Rendah dan Diajar dengan Pembelajaran Konvensional

Berdasarkan tes hasil belajar yang diberikan setelah proses pemberian perlakuan, skor tertinggi pada siswa yang memiliki kecerdasan emosional rendah dan diajar dengan menggunakan pembelajaran konvensional memiliki skor rata-rata $=119,57$; varians $\left(\mathrm{Sd}^{2}\right)=$ 6,133; standard deviasi (Sd) $=6,133$ skor tertinggi $=124$; skor terendah $=107$.

Tabel 7 Hasil Belajar Siswa yang Memiliki Kecerdasan Emosional Rendah dan Diajar dengan Pembelajaran Konvensional

\begin{tabular}{|c|c|c|c|c|}
\hline \multicolumn{5}{|c|}{ DATA KELAS X TGB 2} \\
\hline No. & $\begin{array}{c}\text { No. } \\
\text { Subjek }\end{array}$ & Post Test & $\begin{array}{c}\text { Kec. } \\
\text { Emosional }\end{array}$ & Ket \\
\hline 1 & 3 & 16 & 118 & B2 \\
\hline 2 & 8 & 17 & 118 & B2 \\
\hline 3 & 9 & 14 & 124 & B2 \\
\hline 4 & 14 & 15 & 107 & B2 \\
\hline 5 & 15 & 13 & 124 & B2 \\
\hline 6 & 21 & 19 & 123 & B2 \\
\hline 7 & 24 & 16 & 123 & B2 \\
\hline \multicolumn{2}{|c|}{ Ma } & 15,4000 & 120,2000 & \\
\hline \multicolumn{2}{|c|}{$\Sigma X$} & 77 & 601 & \\
\hline \multicolumn{2}{|c|}{$\Sigma X^{2}$} & 1207 & 72459 & \\
\hline \multicolumn{2}{|c|}{$\mathrm{Sd}$} & 2,302173 & 7,395945 & \\
\hline \multicolumn{2}{|c|}{$\mathrm{Sd}^{2}$} & 5,3000 & 54,700000 & \\
\hline \multicolumn{2}{|r|}{$\mathrm{N}$} & 7 & & \\
\hline
\end{tabular}

Sebelum dilakukan analisis data untuk menguji hipotesis maka data yang diperoleh terlebih dahulu diuji normalitas dan homogenitasnya. Untuk kebutuhan analisis data, maka dari 2 kelompok sampel yang akan diuji normalitas dan homogenitasnya sesuai dengan rancangan penelitian yaitu anava faktorial $2 \times 2$, terdapat kolom 1, kolom 2, baris 1 dan baris 2 .
Dimana masing-masing kelompok tersebut adalah: (1) kelompok siswa yang diajar dengan metode latihan yang memiliki kecerdasan emosional tinggi dan kecerdasan emosional rendah (Kolom 1), (2) kelompok siswa yang diajar dengan pembelajaran konvensional yang memiliki kecerdasan emosional tinggi dan kecerdasan emosional rendah (Kolom 2), (3) kelompok siswa yang diajarkan dengan metode latihan dan pembelajaran konvensional yang memiliki kecerdasan emosional tinggi (Baris 1), (4) kelompok siswa yang diajar dengan metode latihan dan kecerdasan emosional yang memiliki kecerdasan emosional rendah (Baris 2).

\section{Tabel 8 Ringkasan Hasil Analisis Uji Normalitas Setiap Kelompok Penelitian dengan Lilliefors $(\alpha=$ $5 \%)$}

\begin{tabular}{|c|c|c|c|c|}
\hline Variabel & Dk & Lo & Ltabel & Keterangan \\
\hline Kolom 1 & 23 & 0,10753 & 0,1764 & Normal \\
\hline Kolom 2 & 23 & 0,127 & 0,1764 & Normal \\
\hline Baris 1 & 37 & 0,05441 & 0,14373 & Normal \\
\hline Baris 2 & 10 & 0,1255 & 0,258 & Normal \\
\hline
\end{tabular}

Pengujian Homogenitas dilakukan untuk mengetahui variasi populasi bersifat homogen atau tidak homogen. Dimana ketentuan suatu varians dinyatakan homogen jika $\mathrm{F}$ hitung $<\mathrm{F}$ tabel yang dikonsultasikan dengan tabel distribusikan frekuensi dengan taraf signifikan $5 \%$.

Tabel 9 Rangkuman Hasil Perhitungan Homogenitas Varians Antar Kolom

\begin{tabular}{|c|c|c|c|c|c|c|}
\hline KEL. & dk & $1 /(\mathbf{d k})$ & $\mathrm{Si}_{\mathrm{i}}{ }^{2}$ & $\begin{array}{l}\log \\
\mathrm{S}^{2}\end{array}$ & $\begin{array}{c}\text { (dk)Log } \\
\mathrm{Si}^{2}{ }^{2}\end{array}$ & $\mathbf{d} \mathbf{k}\left(\mathrm{S}_{\mathrm{i}}\right)^{2}$ \\
\hline Kolom 1 & 23 & 0,043 & 5,17 & 0,71 & 16,41 & 118,9 \\
\hline Kolom 2 & 23 & 0,043 & 6,12 & 0,78 & 18,10 & 140,9 \\
\hline Jumlah & 46 & 0,086 & 11,30 & 1,50 & 34,52 & 259,9 \\
\hline $\mathrm{S}^{2}$ & 5,6503 & & & & & \\
\hline $\log S^{2}$ & 0,7520 & & & & & \\
\hline B & 34,5954 & & & & & \\
\hline $\mathrm{X}^{2}$ & 0,1653 & & & & & \\
\hline$X_{\text {tabel }}$ & 3,84 & & & & & \\
\hline Status & Homogen & & & & & \\
\hline
\end{tabular}

Pada tabel diatas diperoleh nilai uji barlet, B $=34,595466$ dan ; $\chi_{\text {hitung }}^{2}=0,1653665$. Jika harga Chi kuadrat table pada $\mathrm{p}=0,05$ dengan $\mathrm{dk}$ $=1$ adalah 3,84 yang berarti $\chi_{\text {hitung }}^{2}<\chi_{\text {tabel }}^{2}$ $(0,1653665<3,84)$ maka tidak ada perbedaan varians antara kelompok yang diambil dalam 


\section{Pengaruh Metode Latihan dan Kecerdasan Emosional Terhadap Hasil Belajar Mata Diklat Ilmu Statika dan Tegangan Siawa Kelas X SMK Negeri Binaan Provinsi Sumatera Utara}

penelitian. Maka dapat disimpulkan data hasil belajar kedua kelompok adalah Homogen.

Tabel 10 Rangkuman Hasil Perhitungan Homogenitas Varians Antar Baris

\begin{tabular}{|c|c|c|c|c|c|c|}
\hline KEL & Dk & $1 /(\mathbf{d k})$ & $\mathrm{Si}^{2}$ & $\begin{array}{l}\log \\
\mathrm{S}_{\mathrm{i}^{2}}\end{array}$ & $\begin{array}{l}\text { (dk) } \\
\text { Log } \\
S_{\mathrm{i}^{2}}\end{array}$ & $\operatorname{dk}\left(S_{i}\right)^{2}$ \\
\hline Baris 1 & 37 & 0,027 & 2,24 & 0,35 & 13,01 & 83,1 \\
\hline Baris 2 & 10 & 0,111 & 2,48 & 0,39 & 3,55 & 22,36 \\
\hline Jumlah & 47 & 0,138 & 4,73 & 0,74 & 16,57 & 105,5 \\
\hline $\mathrm{S}^{2}$ & 2,29 & & & & & \\
\hline $\log S^{2}$ & 0,36 & & & & & \\
\hline$B$ & 16,58 & & & & & \\
\hline $\mathrm{X}^{2}$ & 0,03 & & & & & \\
\hline$X_{\text {tabel }}$ & 3,84 & & & & & \\
\hline Status & Hom. & & & & & \\
\hline
\end{tabular}

Pada tabel diatas diperoleh nilai uji barlet, B $=16,586691$ dan $; \chi_{\text {hitung }}^{2}=0,0374818$. Jika harga Chi kuadrat table pada $\mathrm{p}=0,05$ dengan $\mathrm{dk}$ $=1$ adalah 3,84 yang berarti $\chi_{\text {hitung }}^{2}<\chi_{\text {tabel }}^{2}$ $(0,0374818<3,84)$ maka tidak ada perbedaan varians antara kelompok yang diambil dalam penelitian. Maka dapat disimpulkan data hasil belajar kedua kelompok adalah Homogen.

Pengujian hipotesis ini akan diajukan dengan teknik anava 2 jalur. Perhitungan selengkapnya dapat dilihat pada lampiran. Statistik dasar anava 2 jalur. Kriteria pengujian yang digunakan adalah jika $F_{\text {hitung }}$ lebih besar dari $\mathrm{F}_{\text {tabel }}\left(\mathrm{F}_{\text {hitung }}>\mathrm{F}_{\text {tabel }}\right)$ pada taraf signifikan 0,05 maka Ho ditolak dan sebaliknya ( $F_{\text {hitung }}<\mathrm{F}_{\text {tabel }}$ ) Ho ditolak.

Tabel 4 Ringkasan Perhitungan Anava Faktorial $2 \times 2$

\begin{tabular}{|l|c|c|c|c|c|}
\hline \multicolumn{1}{|c|}{$\begin{array}{c}\text { Sumber } \\
\text { varians }\end{array}$} & JK & Db & KR & F $_{\text {hitung }}$ & $\mathbf{F}_{\text {tabel }}$ \\
\hline Antar baris & 31 & 1 & 31 & 8,975 & 4,06 \\
\hline Antar kolom & 31 & 1 & 31 & 8,975 & 4,06 \\
\hline $\begin{array}{l}\text { Kolom dan } \\
\text { baris } \\
\text { (Interaksi) }\end{array}$ & 60 & 1 & 60 & 17,371 & 4,06 \\
\hline $\begin{array}{l}\text { Dalam } \\
\text { kelompok } \\
\text { (kekeliruan) }\end{array}$ & 272,9 & 44 & 6,0204 & - & - \\
\hline Total & 394 & 47 & - & - & - \\
\hline
\end{tabular}

Berdasarkan rangkuman di atas maka akan dirinci pengujian berikut:

\section{a. Hipotesis Pertama}

Pengujian hipotesis pertama untuk mengetahui pengaruh metode pembelajaran terhadap hasil belajar secara matematis dituliskan:

$$
\begin{array}{ll}
\text { Ho } & : \mu \mathrm{A}_{1} \leq \mu \mathrm{A}_{2} \\
\mathrm{Ha} & : \mu \mathrm{A}_{1}>\mu \mathrm{A}_{2}
\end{array}
$$

Diketahui bahwa nilai $F_{\text {hitung }}$ antar kolom lebih besar dari $\mathrm{F}_{\text {tabel }}\left(\mathrm{F}_{\text {hitung }(8,975)}>\mathrm{F}_{\text {tabel }}(4,06)\right.$ ). Dengan demikian Ho ditolak dan Ha yang menyatakan hasil belajar ilmu statika dan tegangan siswa yang diajar dengan metode latihan lebih tinggi dari pada siswa yang diajar dengan pembelajaran konvensional. Dalam hal ini metode latihan lebih baik dari pembelajaran konvensional.

Dengan demikian dapat disimpulkan bahwa hipotesis penelitian yang menyatakan terdapat pengaruh yang positif antara metode latihan terhadap hasil belajar mata diklat Ilmu Statika dan Tegangan.

b. Hipotesis Kedua

Pengujian hipotesis kedua untuk mengetahui pengaruh metode pembelajaran terhadap hasil belajar secara matematis dituliskan:

$$
\begin{array}{ll}
\text { Ho } & : \mu \mathrm{A}_{1} \leq \mu \mathrm{A}_{2} \\
\mathrm{Ha} & : \mu \mathrm{A}_{1}>\mu \mathrm{A}_{2}
\end{array}
$$

Diketahui bahwa nilai $F_{\text {hitung }}$ antar kolom lebih besar dari $\mathrm{F}_{\text {tabel }}\left(\mathrm{F}_{\text {hitung }}=8,975>\mathrm{F}_{\text {tabel }}=4,06\right)$. Dengan demikian Ho ditolak dan Ha yang menyatakan terdapat perbedaan hasil belajar ilmu statika dan tegangan antara siswa yang memiliki kecerdasan emosional tinggi dengan siswa yang memiliki kecerdasan emosional rendah teruji kebenarannya. Dimana siswa yang memiliki kecerdasan emosional memiliki nilai rata-rata yang lebih tinggi dari pada siswa yang memiliki kecerdasan emosional rendah baik itu pada kelas metode latihan dan pembelajaran konvensional.

Dengan demikian dapat disimpulkan bahwa hipotesis penelitian yang menyatakan terdapat pengaruh yang positif antara kecerdasan emosional terhadap hasil belajar mata diklat Ilmu Statika dan Tegangan.

\section{c. Hipotesis Ketiga}

Pengujian hipotesis ketiga untuk mengetahui pengaruh strategi pembelajaran 
terhadap hasil belajar secara matematis dituliskan:

Ho : Interaksi $S><M=0$

Ha $\quad$ Interaksi $S><M \neq 0$

Berdasarkan rata-rata hasil belajar untuk setiap kelompok pembelajaran yaitu, $\bar{X}=18,571$, $2=15,7 \overline{\mathrm{X}} 4, \quad 3=19 \overline{\mathrm{X}} \quad{ }_{4}=1 \overline{\mathrm{X}}, 666$ dari ringkasan faktorial $2 \times 2$ tabel 4.13. di atas terlihat bahwa

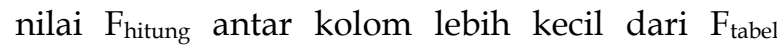
$\left(F_{\text {hitung }}=17,731>F_{\text {tabel }}=4,06\right)$. Dengan demikian Ho ditolak dan $\mathrm{Ha}$ yang menyatakan terdapat pengaruh interaksi antara metode latihan dengan kecerdasan emosional dalam mempengaruhi hasil belajar teruji kebenarannya.

Dengan demikian dapat disimpulkan bahwa hipotesis penelitian yang menyatakan terdapat interaksi antara metode latihan dengan kecerdasan emosional terhadap hasil belajar mata diklat Ilmu Statika dan Tegangan.

Untuk melihat interaksi antara metode latihan dan konvensional dengan tinggi rendah kecerdasan emosional.

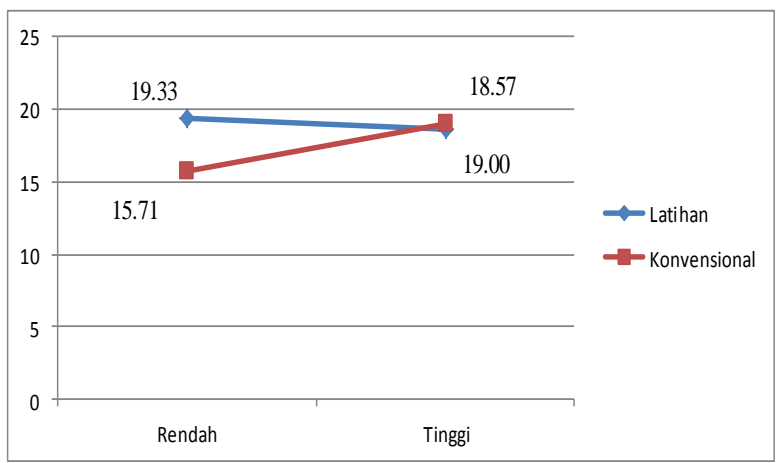

Gambar 1 Interaksi Antara Metode Latihan dan Kecerdasan Emosional

3. Kesimpulan, Implikasi dan Saran

\subsection{Kesimpulan}

Berdasarkan hasil penelitian, maka dapat disimpulkan sebagai berikut :

a. Terdapat pengaruh yang positif antara metode latihan terhaadap hasil belajar siswa pada mata diklat Ilmu Statika dan Tegangan pada data hasil penelitian, dimana $F_{\text {hitung } 8,975}>F_{\text {tabel }} 4,06$ pada kelas $X$ program keahlian Teknik Gambar Bangunan SMK Negeri Binaan Provinsi Sumatera Utara.

b. Terdapat pengaruh yang positif antara kecerdasan emosional terhadap hasil belajar mata diklat Ilmu Statika dan Tegangan, dimana $F_{\text {hitung }} 8,975>F_{\text {tabel }} 4,06$ pada kelas $X$ program keahlian Teknik Gambar Bangunan
SMK Negeri Binaan Provinsi Sumatera Utara. Hal ini juga terlihat dari rata-rata hasil belajar siswa yang memiliki kecerdasan emosional tinggi lebih tinggi nilai rata-rata hasil belajar yang memiliki kecerdasan emosional rendah.

c. Terdapat terdapat interaksi antara metode latihan dengan kecerdasan emosional terhadap hasil belajar mata diklat Ilmu Statika dan Tegangan, dimana $F_{\text {hjtung }}$ $17,371>F_{\text {tabel }} 4,06$ pada siswa kelas $X$ program keahlian Teknik Gambar Bangunan SMK Negeri Binaan Provinsi Sumatera Utara.

\subsection{Implikasi}

Berdasarkan kesimpulan pertama yang menyatakan bahwa metode latihan lebih baik dibandingkan dengan pembelajaran konvensional. Metode latihan lebih membuat siswa memotivasi diri untuk dapat menguasai materi pembelajaran, hal ini dapat dijadikan pertimbangan bagi pihak pengelola SMK Negeri Binaan Provinsi Sumatera Utara untuk mengaplikasikan metode pembelajaran yang lebih tepat.

Hasil simpulan kedua, yang menyatakan bahwa hasil belajar siswa yang memiliki kecerdasan emosional tinggi lebih baik dari pada siswa yang memiliki kecerdasan emosional rendah, hal ini juga dapat dijadikan sebagai bahan pertimbangan khususnya dalam pembelajaran agar dalam setiap penyampaian materi pelajaran harus memperhatikan karakteristik siswa, apakah siswa tersebut memiliki kecerdasan emosional tinggi atau kecerdasan emosional rendah yang dapat mempengaruhi hasil belajar mata diklat Ilmu Statika dan Tegangan.

Hasil simpulan ketiga, yang menyatakan adanya interaksi antara metode latihan dan kecerdasan emosional terhadap hasil belajar siawa. Oleh karenanya perlu ada kesesuaian antara metode pembelajaran dengan karakteristik yang dimiliki siswa serta perlunya peran guru untuk mendorong dan menumbuhkan kecerdasan emosional belajar siswa, sehingga siswa lebih giat dan sungguhsungguh dalam belajar untuk memperoleh hasil yang lebih baik dari hasil belajar yang sudah diperoleh sebelumnya.

\subsection{Saran}




\section{Pengaruh Metode Latihan dan Kecerdasan Emosional Terhadap Hasil Belajar Mata Diklat Ilmu Statika dan Tegangan Siawa Kelas X SMK Negeri Binaan Provinsi Sumatera Utara}

Setelah melihat hasil penelitian, pembahasan dan kesimpulan maka peneliti memberikan saran sebagai berikut :

\section{a. Bagi siswa}

Metode latihan merupakan salah satu usaha untuk membuat siswa memperoleh suatu ketangkasan terhadap apa yang telah dipelajari siswa melalui latihan yang dilakukan secara berulang-ulang. Dengan demikian siswa diharapkan memiliki hasil belajar yang tinggi di dalam menerima suatu materi pelajaran dengan metode latihan, hal ini akan berdampak positif bagi hasil belajar siswa itu sendiri.

\section{b. Bagi Guru}

Dalam kegiatan belajar mengajar guru diharapkan menjadikan metode latihan sebagai suatu alternatif dalam mata diklat Ilmu Statika Dan Tegangan untuk meningkatkan hasil belajar siswa. Guru diharapkan mampu menjadi fasilitator yang memantau secara langsung hasil pekerjaan siswa, guru bisa mengecek hasil pekerjaan tiap siswa, sehingga guru bisa mengetahui di bagian-bagian mana saja siswa mengalami kesulitan menyelesaikan permasalahan materi pembelajaran.

\section{c. Bagi SMK Negeri Binaan Provinsi Sumatera Utara}

Karena kegiatan ini sangat bermanfaat khususnya bagi sekolah, maka diharapkan mendukung pelaksanaan secara berkesinambungan sebagai referensi yang dapat digunakan oleh guru mata pelajaran lain.

\section{Daftar Pustaka}

Aunurrahman. 2009. Belajar dan Pembelajaran. Bandung: Alfa Beta

Abdurrahman, Mulyono. (2012). Anak Berkesulitan Belajar: Teori, Diagnosis, dan Remediasinya. Jakarta : Rineka Cipta

Arikunto, Suharsimi. (2003). Prosedur Penelitian : Suatu Pendekatan Praktik. Jakarta : Rineka Cipta Arikunto, Suharsimi. (2011). Dasar-Dasar Evaluasi Belajar. Jakarta : Rineka Cipta

Bahri, Zein. 2006. Strategi Belajar Mengajar. Jakarta: Rineka Cipta
Bukhari. (2009). Metode Latihan. Diakses pada 2 Juli $2014 \quad$ dari http://bukhari.blogspot.com/2009/01/metodelatihan-revisi.html?m=1.

Davis, Mark. 2005. Uji dan asah Kecerdasan emo anda. Jakarta: Harmoni

Darwis. (2008). Pembelajaran dengan Metode Latihan. Diakses pada 2 Juli 2014, dari http://m.kompasiana.com/post/read/399656/2/pem belajaran-dengan-metode-latihan.html

Dimyati, Mudjiono. 2006. Belajar dan Pembelajaran. Jakarta: Reneka Cipta

Djamarah, S. B. 2006. Psikologi Belajar. Jakarta: Rineka Cipta

Goleman, Daniel. Kecerdasan Emosional. Jakarta: Gramedia Pustaka Utama

Hakim, T. 2005. Belajar Secara Efektif. Jakarta: Puspa Swara

Hamalik, O. 1993. Metode Belajar dan Kesulitan Belajar. Jakarta: Bumi Aksara

Hamalik, Oemar. (2009). Dasar-Dasar Pengembangan Kurikulum. Bandung : PT Remaja Rosdakarya

Hamza. 2006. Perencanaan Pembelajaran. Jakarta: Bumi Aksara

Irwansahaja. (2009). Langkah-Langkah dalam pembelajaran Metode Latihan atau drill. [Online]. Tersedia: http://www.sekolah dasar.net/2012/05/langkah-langkahmetode-latihan.html [diakses 17 Juli 2014]

Keegan, Linda. 2001.Global Marketing Management. Jakarta: Gramedia Pustaka Utama

Mussofa. 2008. Learning Dissability. Jakarta: Harmoni

Purba, R. 1999. Perhitungan Statika Bangunan. Bandung: Angkasa

Purwanto. (2011). Evaluasi Hasil Belajar. Yogyakarta: Pustaka Belajar.

Roestiyah. (2008). Defenisi Metode Latihan. Diakses pada 12 September 2014 dari http://www.pusattesis.com/metode-latihan/

Sagala, Syaiful. (2009). Konsep dan Makna Pembelajaran untuk Membantu Memecahkan Problematika Belajar dan Mengajar. Bandung : Alfabeta

Sanjaya, Wina. (2009). Strategi Pembelajaran: Berorientasi Standar Proses Pendidikan. Jakarta: Kencana Prenadamedia Group

Sardiman. 2007. Interaksi dan Motivasi Belajar Mengajar. Jakarta: PT. Raja Grafindo Persama 
Slameto. 2003. Belajar dan Faktor-faktor yang Mempengaruhinya. Jakarta: Rineka Cipta

Sudjana. (2005). Metode Statistika. Bandung : Tarsito

Sudjana, Nana. (2009). Penilaian Hasil Proses Belajar Mengajar. Bandung : PT. Remaja Rosdakarya

Sugiyono. (2011). Metode Penelitian Pendidikan:Pendidikan Kuantitatif, Kualitatif dan RED.Bandung: Alfabeta

Sugiyono. (2010). Metode Penelitian Kuantitatif, Kualitatif dan RED.Bandung: Alfabeta

Suryabrata, S. 1991. Psikologi Pendidikan.

Jakarta: A 